\title{
The Origins of Rome in the Renaissance
}

\author{
Revival \& Reinvention, Rejection \& Replacement
}

\author{
Susanna de Beer
}

\section{1 \\ Introduction ${ }^{1}$}

This chapter analyses how humanist poets during the Renaissance employed the aetiological discourse concerning the origins of Rome. By this aetiological discourse I do not only mean the foundation myths of Rome themselves, but also the body of ancient literature in which these myths were told, as well as the aetiological thinking and reasoning they reflect. I aim to show that these poets, as well as the influential people for whom they often wrote did not just have antiquarian or literary interest in these ancient foundation myths. Instead, I argue that in essence the same things were at stake for the humanist writers as for their ancient predecessors, when they used aetiological stories to explain and legitimize a certain status quo: a political, cultural or religious institution or practice. ${ }^{2}$ More specifically, I explain how numerous parties (cities, nations, empires etc.) employed the same aetiological discourse not in isolation, but in competition with each other.

\section{$2 \quad$ Revival}

In the following Latin epigram the Italian humanist Aurelio Brandolini hails pope Sixtus IV (1471-1484) as 'second founder' of Rome. ${ }^{3}$ Sixtus is compared and even found superior - to Romulus and all other ancients, being father, god and master all in one.

1 This work was supported by grants from The Netherlands Organization for Scientific Research (NWO). I am also very grateful for the feedback received from the audience and organizers of the conference Inventing Origins, and from the anonymous reviewer. Finally, many thanks to Caroline van den Oever for reading and thinking along in various stages of this project.

2 See Fantuzzi and Rüpke 2006.

3 For Brandolini's life and works see Rotondò 1972. For his poetry for Sixtus IV see De Luca 1938. Some of his poems are also quoted in Blondin 2005. 
Aurelio Brandolini, 1.18.26-31; 36-37

Ausus at est Sixtus veteremque resurgere solus

Iussit Romam, immo condidit ipse novam;

Reddidit hic urbi formam veteresque ruinas

Substulit: et passim coctile fecit iter.

Nobile pontis opus struxit delubra refecit. [30]

Multa quidem: fecit sed nova plura tamen. [...]

Romule, cede pater, veteres concedite cuncti.

Hic urbis pater est. Hic deus, hic dominus.

But Sixtus dared this and he alone ordered old Rome to rise up again; no, actually he himself founded a new Rome! This man returned beauty to the city and he removed the old ruins and he laid out in all directions a road of baked brick. He built a famous work of a bridge and he restored churches, many to be sure, but he built still more new ones. [...] Father Romulus, yield! All ancients, yield! He is the father of the City. He is god and he is master. ${ }^{4}$

Brandolini's poem is typical for how humanist poets employ the ancient aetiological discourse regarding Rome, in that it connects to all three levels mentioned above. First, it refers to the concrete foundation myth of Rome by Romulus. Second, it directly alludes to ancient literary examples in which these aetiologies were mentioned by means of intertextual references, among others, Ovid's Fasti. Finally, it adopts similar strategies of using this aetiological myth for purposes of political legitimization like those used by ancient poets.

The specific interest displayed by Renaissance princes and poets in the mythical origins of Rome in particular, can be explained by the fact that in medieval and Renaissance Europe the ancient Roman Empire still functioned as the basic template for legitimizing political power and cultural authority. ${ }^{5}$ As a result, to claim the kind of power and authority associated with the ancient Roman Empire, Renaissance writers argued that the origins of Rome were their origins too. This aetiological reasoning can be considered a specific, very powerful method of backing up heritage claims. ${ }^{6}$ To support heritage

4 Text and translation in Blondin 2005, 4.

5 See e.g. Dandelet 2014 and Enenkel and Ottenheym 2017, especially chapters 1-3.

6 See Graham and Howards 2008; Lowenthal 1985 and idem 1998. I have explained in greater depth the benefits of a heritage approach for the analysis of humanist Latin poetry about Rome in De Beer 2o2ob. 
claims one has to argue for a privileged link with a certain positive past. The further back that past can be traced, the more authoritative the claim is usually considered to be. As a consequence, privileged links with origins are regarded as very powerful tools in such claims. ${ }^{7}$

In the Renaissance, given the general high authority of Antiquity in this period, the best strategy for any heritage claim was to argue for a privileged link with specifically ancient origins. If such claims, in addition, employed the specific literary or artistic language of Antiquity, they were considered particularly powerful and authoritative. ${ }^{8}$ This is exactly what happens in Renaissance Rome, where the Roman foundation myths were revived to play a key role in papal politics, as can be exemplified by the pontificate of Sixtus IV. In this case, restoring the link between the mythical past and the present served to underline the legitimacy of papal power on the grounds of its proposed continuation of the ancient Roman imperium..$^{9}$ As a result, this mythical past is fervently explored in literature of the time, as testified by Brandolini's epigrams for Sixtus IV, but also e.g. by Andrea Fulvio's De Romuli et Remi expositione or Raffaele Maffei's poem De origine urbis. ${ }^{10}$

However, the importance of Rome's origins in the Renaissance can not only be inferred from literature, but also from papal interferences in the city itself, such as Sixtus' transference of the famous bronze statue of the she-wolf from the Lateran to the Campidoglio, and from his commission to add the figures of Romulus and Remus to the statue. ${ }^{11}$ During his pontificate the places associated with Rome's origins were also examined with special interest, as shown by contemporary excavations at the Forum Boarium, the location where Aeneas famously heard the story of Hercules. ${ }^{12}$

In adopting this strategy of revival, the Popes benefited from the continuity of the location, which constituted their privileged link with the ancient

$7 \quad$ See Lowenthal 1998, especially chapters 8 and 9, which deal with the arguments of priority and rootedness, which both related to the idea of origins.

8 For the revival of Latin language and literature as a central mission of humanism, see Baker 2017.

9 For the idea of Rome and the Roman Empire in Renaissance religious thought see O'Malley 1968, especially 118-138. For the reception of the Aeneid to this purpose, see Hardie 2014, especially chapter 6 ('Imperium sine Fine: The Aeneid and Christianity'), which explains how the Imperium Christianum was considered a continuation of the Imperium Romanum.

10 See Muecke 2007.

11 For this aspect of Sixtus' papacy see Blondin 2005; Miglio et al. 1986.; Benzi 1990; and Benzi et al. 2000.

12 Verg. A. 8.190-305. For these excavations see Parisi Presicce 2000. 
Roman past, and offered the opportunity to make visible places and works of art connected to the foundation myths. They could still be pointed out in the Roman landscape or put on display as lieux de mémoire. ${ }^{13}$ At the same time the Renaissance Popes had the disadvantage that the ancient Roman city had fallen severely into ruin, which could also be considered a sign of discontinuity between ancient and Renaissance Rome. To deal with this disadvantage effectively, the papal propaganda, alongside a focus on Rome's origins, also adopted the scheme of the renovatio imperii and the idea of a Golden Age returned. ${ }^{14}$

In so doing, the Popes imitated a method that had formed the core of the Augustan propaganda as well. Seen from this perspective, Brandolini's epigram grants Sixtus a double privilege: it not only creates a link between him and Rome's mythical past by comparing him to Romulus; it also aligns him with Augustus, pointing to both their efforts to 'renew Rome..15 This is thus the origin of Pope Sixtus IV as the Restaurator Urbis. The allusion to Ovid's Fasti can also be seen in this light. To claim Sixtus' superiority over Romulus, Aurelio Brandolini uses a phrase comparable to the Ovidian Romule, concedes (Fast. 2.133) and portrays him as the father of Rome, just as Ovid had called Augustus pater patriae (Fast. 2.127) and pater orbis (Fast. 2.130). ${ }^{16}$ However, whereas Ovid compares Augustus' rule over the earth with Jupiter's rule over heaven, Brandolini presents Sixtus as pater, as well as deus and dominus. ${ }^{17}$ As a consequence, Sixtus is represented as a city founder who outdoes Romulus and Augustus and is at the same time associated with the Christian Lord. ${ }^{18}$

However, the Popes were by no means the only party in Renaissance Europe that claimed Roman origins, thereby legitimizing the power and authority represented by the Roman Empire. In the remainder of this chapter we will see what kinds of strategies were open to poets representing other political, religious or cultural powers to employ the same or similar aetiological stories

13 For this concept see Nora et al. 1984-1992. For the collection and display of antiquities to this purpose see Christian 2010.

14 See Stinger 1985, especially chapters 5 and 6.

15 More on this relationship between Renaissance and Augustan Rome, see De Beer forthcoming.

16 For modern takes on (the forthrightness of) Ovid's praise of Augustus in the Fasti, see e.g. Hinds 1992 and McKeown 1984.

17 Ov. Fast. 2.132 (hominum tu pater, ille deum).

18 Dominus et Deus is how God is addressed, among others, in the Book of Revelation 4.11, but it is also the formula by which Emperor Domitian was often named, for example in several of Martial's epigrams (among others in 5.8.1, 7.34.8, 8.2.6, 9.66.3, and 10.72.3). For the relationship between this imperial and religious discourse see Thompson 1990, 104-107. 
and to argue for their privileged link with these Roman origins. Alongside the revival of these myths, as we have seen in Brandolini, we will encounter examples of their reinvention, rejection and replacement. By applying insights from heritage studies, this chapter seeks to understand what goals these different ways of appropriating the Roman aetiological discourse served, and what they can teach us about the role of aetiological reasoning in the relationship between past and present.

\section{$3 \quad$ Reinvention}

Pierre de Ronsard, La Franciade 1.1-12

Muse qui tiens les sommets de Parnasse

Guide ma langue e me chante la race

Des Rois François yssuz de Francion

Enfant d'Hector, Troyen de nation

Qu'on apelloit en sa ieunesse tendre

Astyanax et du nom de Scamandre.

De ce Troyen conte moy les travaux

Guerres, desseins, et combien sur les eaux

Il a de fois (en despit de Neptune

Et de Iunon) surmonté la Fortune

Et sur la terre eschapé de peris,

Ains que bastir les grands murs de Paris.

Muse atop the summits of Parnassus, steer my speech and sing for me that race of French kings descended from Francion, Hector's son and of Trojan stock, who in his tender childhood was called Astyanax or by the name Scamandrius. Tell me of this Trojan's misfortunes, of the wars he fought, of his mission, and tell me how many times on the seas (despite Neptune and Juno) he overcame Fortune, and how many times on solid ground he escaped from danger, before going on to build the walls of Paris. ${ }^{19}$

These lines are the beginning of the national epic La Franciade by Pierre de Ronsard - a work which was begun before 1572 , but was never completed. This passage is clearly modelled on the opening lines of the Aeneid and connects to

19 Text from Ronsard 1993. Translation adapted from Ronsard 2010. 
the same Trojan origins that are fundamental in the aetiology constructed in that epic poem. ${ }^{20}$ However, the aetiological story itself is reinvented, as it does not lead to the foundation of Rome by Aeneas, but to the foundation of Paris by Francion or Francus. ${ }^{21}$

These opening lines might come across to us as a parody, but we should keep in mind the basic premises: the issue of political legitimization was of very real importance in this period, the use of the past for this purpose was completely natural, and ever since its publication, the Aeneid had been the most authoritative source for this message and method. ${ }^{22}$ The great advantage of the Aeneid is that it not only emphasizes the importance of Rome's location for its foundation, but also includes and thus legitimizes the scheme of the translatio imperii (the transfer of the imperium) as a basic element in the foundation of a world empire. This made this specific myth of the origin of Rome via Trojan roots much easier to appropriate for non-Romans than, for example, the story of Romulus and Remus. Foreign claimants might not own the location of Rome, but were still able to create a privileged link to these Trojan roots of Rome via genealogy, as we see in Ronsard's example.

However, there is an inherent paradox in the Franciade, as in other such alternative genealogies. Although it clearly imitates the Aeneid and owes its rhetorical power to that model, it also strongly opposes and competes with the foundation story told in the Aeneid at the same time. By letting Paris be founded directly by a Trojan prince, it neglects the importance of Aeneas and overwrites the foundation of Rome with an alternative story based on the same authoritative origins. Seen from the viewpoint of heritage studies this is completely natural, since heritage claims are always competitive, and part of a process of inclusion and exclusion. ${ }^{23}$ By claiming Trojan origins for her own purpose, France automatically competed with Rome, whose origins were

20 E.g.Verg.A.1.5 (multa quoque et bello passus);1.3 (et terris iactatus et alto);1.4(saevae memorem Iunonis ob iram); 1.7 (altae moenia Romae); 1.6-7 (genus unde Latinum/Albanique patres). I owe these specific references to the anonymous reviewer of this chapter.

Francion or Francus was considered to be the same as Astyanax, the son of Hector, who was renamed by the Greeks after they had taken Troy. See Beaune 1985, chapter 1, esp. 19-30.

For the reception of the Aeneid in this manner, see Hardie 2014, especially chapter 5 (Empire and Nation), which focuses on the inclusion in the Aeneid of both the translatio from Troy and the renovatio of Saturnus' reign.

23 See Tunbridge and Ashworth 1996. Indeed, the Aeneid itself bears witness to the competitiveness of heritage claims: Virgil's claim, in the epic's very first verse, that Aeneas was 'first' (primus) of the Trojans to reach Italy, is disputed in the same text when soon after Venus states Antenor had already settled in Patavium - while Aeneas himself is yet 
found in this same Trojan heritage. This process reflects the political, religious and cultural landscape of the time, in which France competed with Italy for cultural primacy. In this same context we could also consider the following contemporary sonnet that the famous French humanist Joachim Du Bellay dedicated to Ronsard:

\section{Joachim Du Bellay, Les Regrets 19}

Ce pendant que tu dis ta Cassandre divine, Les louanges du Roy, et l'heritier d'Hector, Et ce Montmorancy, nostre François Nestor, Et que de sa faveur Henry t'estime digne:

Je me pourmene seul sur la rive Latine,

La France regretant, et regretant encor Mes antiques amis, mon plus riche tresor, Et le plaisant sejour de ma terre Angevine.

Je regrete les bois, et les champs blondissans, Les vignes, les jardins, et les prez verdissans Que mon fleuve traverse: icy pour recompense

Ne voiant que l'orgueil de ces monceaux pierreux,

Où me tient attaché d'un espoir malheureux Ce que possede moins celuy qui plus y pense.

While you sing your divine Cassandre, the praises of the king and Hector's heir, and Montmorancy our French Nestor, and while Henry judges you worthy of his favor, I wander alone on the Latin shore, longing for France, and longing, too, for my old friends, my richest treasure and for my pleasant Angevin home. I miss the woods and the ripening fields, the vines, the gardens, and the meadows turning green through which my river runs: here instead of all that, seeing only the pride of these piles of stone, where I am held by a vain hope for that which he least attains who desires it most. ${ }^{24}$

stranded on North African shores (Verg. A. 1.242-249; cf. also Ov. Fast. 4.77-78). Servius (ad loc.) attempts to reconcile the apparent contradiction in $A$. 1.1.

Text in Du Bellay 1966. Translation in Du Bellay 2006. 
In the first quatrain of this poem Du Bellay hints at the Trojan origins of France through a reference to La Franciade, which, as we have seen, traces France's origins back to the Trojan Hector (1. 2: l'heritier d'Hector). Du Bellay then contrasts Ronsard's literary activities in France to his own stay in Rome (1. 5: la rive Latine), which he represents as an unwanted exile. Du Bellay indeed visited Rome in the retinue of his uncle Jean du Bellay in the 1550's. To understand why he represented his stay in Rome as an exile in this poem, we can best compare it to his much more elaborate Latin elegy Patriae desiderium, of which this sonnet forms a partial translation. ${ }^{25}$

This Latin elegy playfully imitates and contrasts with Ovid's exile poetry, putting France in the place of Rome, and Rome in the place of Tomis. However, unlike Tomis, in Du Bellay's poetry Rome is not the stereotypical uncultivated and thus unattractive place; it has lost its attraction. This loss of attraction is exemplified in the sonnet by the Roman ruins (1. 12: ces monceaux pierreux), the 'dead Rome' in which Du Bellay is still stuck, while longing for the 'new Rome' that is inhabited and shaped by Ronsard: France. By this means, the sonnet exemplifies the inherent connection between the two ways of challenging the Roman revival of the aetiological discourse: by reinventing and rejecting it.

\section{4}

Rejection

We have already observed that Roman humanists like Brandolini accommodated the Roman ruins by inscribing them into their discourse of the renovatio Romae. Now we see that their competitors instead used them as proof that Renaissance Rome was no longer the same as ancient Rome. In his Latin Descriptio Romae Du Bellay again returns to this image of Roman ruin and decay:

Joachim Du Bellay, Descriptio Romae 129-133

Caetera tempus edax longis tegit obruta seclis, Ipsaque nunc tumulus mortua Roma sui est. Disce hinc humanis quae sit fiducia rebus:

Hic tanti cursus tam brevis imperii.

Devouring time covers everything else, overgrown during long centuries, and now dead Rome herself has become her own tomb. Learn from this

25 This is elegy 7 , text in Du Bellay 1984. See further on this elegy IJsewijn 1991. On Du Bellay's translation practices see Ford 2013, chapter 2. 
what faith to put in human affairs: this is the short lifetime of such a great empire. $^{26}$

Not only is Renaissance Rome different than ancient Rome, in Du Bellay's opinion, ancient Rome is dead. Apart from the fact that this image allows for reflections on Rome as a symbol for the vicissitudes of Fortune and of devouring time herself, Du Bellay's poem can also be seen to undermine the papal revival of the aetiological discourse of Rome. ${ }^{27}$ By presenting Rome's link with her own ancient past as broken, it renders illegitimate the papal claim on the Roman origins. Furthermore, through its emphasis on the definitive and irreversible end of Rome, exemplified by the image of death, it counters the scheme of a renovatio Romae that was so central to the image of papal Rome.

The question remains why these Roman claims had to be countered, or disarmed explicitly. Why was it not enough for the competitors of Renaissance Rome, like the French Ronsard or Du Bellay, to reinvent an alternative and competitive aetiology and leave it at that? To understand this, we have to return to the functioning of heritage again. As we have already observed, the condition for any heritage claim is to have, or at least to argue for, a privileged link with that past. We have also seen that such a privileged link could be constituted by the continuity of location (as in papal Rome), or by a continuous genealogy (as in Ronsard's Franciade). From this point of view we can also understand the exceptional power of the aetiology in Virgil's Aeneid, combining as it does these two strategies into one mythological story.

However, of these two rhetorical strategies, the first one is regularly considered the more convincing one: a link constituted by the continuity of location and by the rootedness of the present in the past, is more privileged than a link on the basis of genealogy. ${ }^{28}$ We can see this preference already in the foundation myth of Rome, where the fall of Troy is a condition for the foundation and flourishing of the Roman Empire. When, in Lucan's Bellum civile, Caesar suggests that Troy will be rebuilt, this is regarded as a direct attack on the legitimacy of, and threat to the existence of Rome. ${ }^{29}$ We can understand this if we consider that Troy's claim to her own local origins will always be stronger than those of Rome, which were essentially based on a translatio.

26 Text in Du Bellay 1984. See further Horstmann 2010.

27 The devouring time is a reference to Ov. Met. 15.234-236 (tempus edax rerum, tuque invidiosa vetustas/omnia destruitis vitiataque dentibus aevi/paulatim lenta consumitis omnia morte!).

28 See Lowenthal 1998, especially chapter 9, and Kennedy 1999.

29 Luc. BCiv. 9.990-999. See Edwards 1996, 65. 
Now it is this exact same scheme, the same combination of claims and attacks, that underlies the Renaissance attempts to undermine the papal claims to ancient Rome. Again, by so doing they not only directly appropriate the foundation myth of Rome for their own specific goal, by turning Renaissance Rome into ruined Troy, but they are also subject to the same heritage schemes that their ancient predecessors were confronted with. In this scheme, only if Rome were dead, (i.e., if the continuity of location changed into a discontinuity) would the arguments for a translatio imperii on the basis of Trojan genealogies be considered legitimate.

In line with this observation, many of the Renaissance poets who reinvent the ancient aetiological discourse of Rome to legitimize the foundation of a different city than Rome, at some point also criticize the Rome of their time in an attempt to oppose the Roman revival of this same discourse. We do not only find these anti-Roman sentiments exclusively in France, but also for example in the context of the Holy Roman Empire, another competitor of the Papal States. ${ }^{30}$ Consider for example the following epigram by the German humanist and poet Conrad Celtis, who was crowned poet laureate by the Holy Roman Emperor Frederick III and later worked in the service of Emperor Maximilian to create a kind of German Renaissance. ${ }^{31}$ In the epigram, the body of an ancient girl who has recently been dug up is presented as speaking and reflecting on the differences between Antiquity and the present state of Rome:

\section{Conrad Celtis, Epigram 3.40: De puella Romae reperta}

Annos mille super tumulo hoc conclusa iacebam;

haec nunc Romanis extumulata loquar:

Non veteres video Romano more Quirites,

iustitia insignes nec pietate viros.

Sed tantum magnas tristi cum mente ruinas

conspicio, veterum iam monumenta virum.

Si mihi post centum rursus revideberis annos,

nomen Romanum vix superesse reor.

\section{About a girl discovered in Rome}

More than a thousand years I have been buried in this tomb; now, having been dug up I shall say these things to the Romans: I do not see the old Quirites, with their Roman ethos, neither do I see men famous for their

$30 \quad$ Hirschi 2012, especially chapter 7 (Humanist Nationalism); and Stadtwald 1996.

31 On Conrad Celtis in the context of German Humanism see especially Robert 2003. 
justice and sense of duty. But, saddened, I only see enormous ruins, now reminding us of people of the past. If I will see you again in a hundred years from now, I think the Roman name will hardly have survived. ${ }^{32}$

The main point of this epigram is similar to the passage by Du Bellay quoted above: Renaissance Rome is nothing like ancient Rome anymore. Thus Celtis too rejects the papal discourse of renovatio by cutting the link between past and present Rome, or in other words, by 'proving' the discontinuity between the foundation of Rome and the Renaissance city. Interestingly, in his image of the Roman ruins as 'monuments of men of old', Celtis refers to Virgil's Aeneid 8, where Aeneas visits the future site of Rome with Evander and already back then stumbles on monuments of an earlier past. ${ }^{33}$ In Celtis' poems this can be regarded as an ironic twist, since it instead represents the Roman aetiological poem par excellence as a poem about Roman ruins. ${ }^{34}$

However, unlike Du Bellay, Celtis does not only emphasize the state of ruin or neglect of Rome's cityscape, he also emphasizes the contrast between the past virtues and the present vices of Rome. This focus on morality was clever, because from the foundation onwards it was part and parcel of the Roman self-image to consider theirs the City of Virtue. It was actually taken for granted that the divine sanction of the Roman Empire was based on the virtue of the Romans directly. ${ }^{35}$ Removing virtue from Rome would therefore also counter Rome's claim on the continuity of this empire. ${ }^{36}$

Thus, in short, the method by which the papal discourse is rejected in this poem consists of the following assumptions: first the original magnificence

32 For this epigram see Martínek 1982, who corrects the text found in Celtis 1963, 57. I have also discussed this epigram in De Beer 2020a. Celtis refers to the excavation of the well-preserved corpse of a girl on the Via Appia in 1485, about which he must have heard during his stay in Rome from 1487 to 1489 . Celtis is not the only poet using an ancient character coming alive to reflect on the changed face of Rome. Cristoforo Landino imagines Augustus coming alive again in Xandra 2.30, 21-24, cf. Pieper 2008, 252-261; and Paolo Spinoso stages the Sarcophagus of Santa Costanza speaking, cf. Bianchi 2004, 163.

The specific reference is to Verg. A. 8.356 (reliquias veterumque vides monimenta virorum).

34 Edwards 2015 .

35 See Edwards 1996, 21sq. for this close connection between empire and moral superiority.

36 See Edwards 1993, 19, for the city of Rome being a crucial reference point for Roman moralists already in Antiquity. This reasoning on the basis of morality fits very well, is actually intertwined, with the religiously inspired anti-Roman sentiments, since virtue is also a key element of the Christian discourse. It was even part of this sentiment to consider Rome saved from her vices exactly by converting to the Christian religion, cf. Stadtwald 1996, 44 . 
and virtue of ancient Rome are accepted, then the continuity between present Rome and this glorious past is denied, and finally the poet emphasizes that this change is irreversible. However, in addition to arguing for Roman immorality by assuming a movement of moral decline, often from antiquity onwards, it could also be argued for by presenting it as a stereotypical Roman trait. Consider the following example, again by Celtis, in which he presents Romulus as speaking to the Romans:

\author{
Conrad Celtis, Epigram 3.13: Vox Romuli ad Romanos \\ Vestalis mihi mater erat, rapiens lupa nutrix, \\ regnaque vulturibus sunt mea structa feris. \\ Hinc tria vos capiant speciosa flagitia cives: \\ stupra, gula et saevae mentis avaritia. \\ Nec vos fasque pium moveat, nulla ira deorum, \\ maximus in coelis Mars pater illa tegat.
}

\title{
The voice of Romulus addressing the Romans
}

A Vestal virgin was my mother, a greedy wolf my nurse, and my kingdom was built on wild vultures. Hence three splendid vices can take possession of you, citizens: sexual immorality, gluttony and avarice of a savage mind. And lest religious law or the anger of the gods move you, your greatest father Mars protect these vices in heaven. ${ }^{37}$

Whereas this second epigram has a similar message to the first, i.e. Renaissance Rome is a den of immorality, the method by which it is reached is the complete opposite. Now Celtis takes some important elements from the foundation myths of Rome and has them represent, or even suggests they caused, the inborn vices of the Romans. ${ }^{38}$ Romulus' descent from Rhea Silvia, a Vestal virgin, is a sign of sexual license; his being nursed by a wolf a sign of gluttony and greed; and the fact that he triumphed over Remus because he saw twelve instead of six vultures a sign of avarice and savagery. Finally, Romulus' father Mars, the god of war, represents the Romans' lack of reverence for religious laws, which explains the proliferation of these vices.

These interpretations of the myth can thus be considered aetiologies in their own right: the origins of Rome being used as explanations of a certain status $q u o$. This trope too, that vice was native to the Romans, infused in Rome's very

37 Text in Celtis 1963, 49 .

38 The argumentative structure of the epigram points in the same direction, with the deictic 'hinc' in l. 3. For the Neo-Latin epigram in general see De Beer, Enenkel and Rijser 2009. 
foundation, can be traced back to ancient texts. ${ }^{39}$ But of course they are more than that, as Celtis did not randomly select his stories. They are exactly the same myths that the contemporary papacy adopted to legitimize their power. However, picking up on the ancient discourse on Roman decadence, Celtis' interpretation of the Roman origines is exactly opposite to the one we find in the papal aetiological discourse of Rome. In this manner Celtis ridiculed the stories and rejected their positive message, while still adopting the same method as his opponents.

What stands out from these two examples by Celtis is that he was absolutely inconsistent in how he rejected the papal discourse, and how he reached the conclusion that Rome was a den of immorality. In fact, the two strategies he adopts are logically incompatible. Whereas the first one regards Rome's immorality as the result of a movement of moral decline, the second one sees it as an unchanging, timeless, stereotypical characteristic of Rome. The first thus assumes ancient Rome to have been a virtuous place, whereas the second one assumes Rome to have been immoral from her origins onwards. In each case he thus agrees with his papal opponents in certain respects, but opposes them in others. In the first case he agrees with them on the virtuous origins of Rome, and in the second on the continuity between ancient and contemporary Rome as being essentially the same.

Not only in Celtis' epigrams, but in the Renaissance discourse of Rome at large, it appears completely normal and acceptable for authors to adopt opposing strategies when it comes to the link between past and present. We could see this as a reflection of their complete and ruthless dedication to their goal, which they wanted to reach no matter what the cost. However, this paradox is also in some ways inherent in the aetiological discourse of Rome itself, which thrives on the positive associations of the ancient Roman heritage, but is used in a highly competitive setting. Moreover, the various strategies adopted by the humanists were directly taken from ancient literature, which they cleverly played out against each other. ${ }^{40}$

\section{5}

\section{Replacement}

This combining of strategies is also obvious in Celtis' Inaugural Lecture at the University of Ingolstadt, held in 1492:

39 E.g. Hor. Epod. 7; Liv. 1.6.4. (avitum malum, regni cupido).

$40 \quad$ See Hardie 1992. 
5. (1) Sed ad vos ego iam, nobiles viri et adolescentes generosi, orationem converto, ad quos avita virtute et Germano illo invicto robore Italiae imperium commigravit [...] (7) Tollite veterem illam apud Graecos, Latinos et Hebraeos scriptores Germanorum infamiam, qua illi nobis temulentiam, immanitatem, crudelitatem et, si quid aliud, quod bestiae et insaniae proximum est, ascribunt. (8) Magno vobis pudori ducite Graecorum et Latinorum nescire historias et super omnem impudentiam regionis nostrae et terrae nescire situm, sidera, flumina, montes, antiquitates, nationes, denique quae peregrini homines de nobis ita scite collegere [...].

But I now turn to you, celebrated men and well-born youths, to whom by the virtue of our ancestors and by that invincible German strength the Italian empire has migrated [...]. Wipe away the hackneyed slanders against the Germans by the Greek, Latin and Hebrew writers who ascribe to us drunkenness, savagery, barbarity and everything else brutish and deranged. Consider it shameful to be unfamiliar with the histories of the Greeks and Latins, and consider it beyond all shame to be unfamiliar with the territory, stars, rivers, mountains, antiquities and nations of our own region and our own land, and with all the things that foreign people have skillfully collected about us. ${ }^{41}$

In the first sentence Celtis claims the imperial power associated with the Roman empire for Germany, by assuming the translatio imperii on the basis of German virtue. ${ }^{42}$ German power thus has a 'Roman' origin. At the same time Celtis assumes an inborn, 'German', origin of this same greatness. At least, for these German youths at the University of Ingolstadt he emphasizes that even more important than the Roman past is to know the German past. ${ }^{43}$ This seeming paradox can be solved by stating that in Celtis' view only the German virtue is inborn, and that on this basis the imperial power which used to be

41 Text in Celtis 2003, 16-40. Selection and translation (with my adaptions) from Collins 2012.

42 See Goez 1958; Renger and Wiesehöfer 2006; and specifically in the case of the Holy Roman Empire: Kunst 2006. For how the concept was adopted by Celtis, see a.o. Hirschi 2012, 16o. Generally speaking, humanists found legitimization of this historical scheme both in the translatio imperii from Troy to Rome as narrated in the Aeneid (cf. Hardie 2014, 104), as well as in the prophecies in the Old Testament Book of Daniel, on which the teaching of the Four Kingdoms was based (cf. Enenkel and Ottenheym 2017, 78).

Borchardt 1971. 
Roman in origin has been transferred to them. This does not necessarily render them Roman in all respects.

However, instead of picking on paradoxes, let us consider the question of why Celtis focuses on German origins in the first place, and how it is connected to the rest of his thought. For if the inaugural lecture presents Celtis' theory, we can see how it works in practice in the following passage from his poetic Germania generalis, in which he writes the following:

Conrad Celtis, Germania generalis 6o-65

Indigena [sc. gens] haud alia ducens primordia gente

Sed caelo producta suo, Demogorgonis alvus

Protulerat patulas ubi cuncta creata sub auras.

Germanos vocitant Itali, Graij sed Adelphos,

Quod fratrum soleant inter se vivere more:

Nomen, nobilibus quod adhuc venerabile nostris.

An indigenous people, not deriving its origin from another people, but produced under its own heaven, when the womb of the Demogorgon had produced everything that was created under the wide skies. The Italians call them 'Germans', but the Greeks 'Adelphoi', because they used to live among each other as brothers: a name that is still honored by our noblemen. ${ }^{44}$

In this passage the key term is 'indigenous'. By emphasizing that the Germans have local origins, Celtis uses the strong rhetorical power of heritage claims based on rootedness and location. Thus we may conclude from this passage that the German people, created indigenously from German soil, are still the same and still display the same characteristics as their ancient ancestors. This kind of reasoning also has the advantage that it can operate separately from Rome, and that it can replace a reasoning based on Roman origins.

However, Rome is never far away. First: the history of the Germans that is told in the Germania generalis, and in which the youths from Ingolstadt should be more interested than that of the 'Greeks and the Latins', is primarily found in ancient Roman sources. In fact, in the same sources as 'the hackneyed slanders against the Germans' are found, which the students should 'wipe away'. Celtis cleverly avoids saying it, but in reality the people who slandered Germany

Text and commentary in Celtis 2001. 
are the same foreign people who skillfully collected all the information about them in the first place: ancient Roman historians like Tacitus.

Just as Ronsard explicitly referred to the Aeneid and used the same aetiological thinking as Virgil to reach a different conclusion, here we can observe how Celtis explicitly refers to ancient Roman aetiological thought about Germany and turns it to his advantage. In fact, by claiming the Germans' superiority because they are indigenous, Celtis uses in reverse the exact same arguments once made by Tacitus to prove their barbarism: that they are untainted 'noble savages', and that they are the product of their peculiar harsh climate. ${ }^{45}$ Thus Celtis appropriates the image of Germany created by the Roman historians and turns the traditional contrast between Roman virtue and German vice into its opposite. Seen from this perspective it is actually to the Germans' advantage that they do not stem from the Romans, who we have seen in Celtis' epigrams to be morally bankrupt. ${ }^{46}$

Rome is not far away in another respect as well. By focusing on the local origins of German greatness, Celtis could impose a similar scheme of decline and renewal (renovatio) on the same location that had been so central to the Italian Renaissance's discourse about Rome. In this way he generated a German-based Renaissance instead of an 'imported' Roman-based Renaissance. This was however in many ways still an imitation of the Italian Renaissance. ${ }^{47}$ We can see to what extent Celtis in fact adopted Italian strategies for example in his efforts to write a history of Germany (Germania illustrata), clearly inspired by Biondo's antiquarian works on Rome and Italy (e.g. his Italia illustrata). ${ }^{48}$ German and Italian humanists nevertheless held different views on what exactly constituted the period of decline in between, the Germans having a much more positive view of their own 'Middle Ages' than the Italians. ${ }^{49}$

45 I owe the formulation of this paradox and specific references to Tacitus to the anonymous reviewer. Cf. Tac. Germ. 2.1 (ipsos Germanos indigenas crediderim). For caelo producta suo (vs. 61) see Tac. Germ. 2.2 (quis porro, praeter periculum horridi et ignoti maris, Asia aut Africa aut Italia relicta Germaniam peteret, informem terris, asperam caelo, tristem cultu aspectuque nisi si patria sit?). About the reception of Tacitus in Germany, see Krebs 2005; and Krebs 2011.

46 The contrast between German virtue and Roman vice is also implied in this passage, in which the peaceful cohabitation of the Germans 'as brothers' triggers the memory of the fratricidal nature of the Romans, exemplified by Romulus killing his brother Remus (with thanks to Jacqueline Klooster for this suggestion).

47 For (the incompatibility of) these two kinds of thought in Celtis see Jaumann 1999.

48 For this project, to which the Germania generalis also belonged, see Collins 2012 and Celtis 2001, 441-483.

49 That said, it is equally important to realize that a large part of what we nowadays consider medieval was actually regarded ancient by the humanists, as explained in Enenkel and Ottenheym 2017, 76-88. 


\section{Conclusion}

In referring to and reflecting on the origins of Rome, Renaissance poets employed the ancient aetiological discourse in similar ways as their ancient Roman predecessors had. In their aetiologies they used the same myths, the same literary templates, and had the same objectives: to legitimize a certain political, cultural or religious status quo. However, since the status quo that had to be legitimized was not the same, the resulting aetiologies were not exactly the same either.

During the Renaissance there were many different parties (e.g. cities, nations, empires) interested in claiming ancient Roman origins as these were still the most authoritative origins one could wish for. This resulted on the one hand in various strategies to argue for a privileged link with these ancient origins, by reviving or reinventing the Roman foundation myths. On the other hand, because of the competitive nature of heritage, the process gave way to various strategies to undermine the privileged links of others, by rejecting the Roman origins. Finally, in an attempt to appropriate the powerful scheme of a renovatio, some shifted the attention to local instead of Roman origins.

Which strategy was chosen depended on the specific goals that had to be served. Whereas the Popes, who had the advantage of location, could simply revive the Roman foundation myths, non-Roman (or non-Italian) parties often combined the other strategies to make their own case as strong as possible and to weaken the Roman case at the same time. In all of this, they did not care too much for consistency, but focused on the message instead.

What all these strategies have in common is that they were adopted and derived their authority from the ancient aetiological discourse, which turned out flexible enough to accommodate all these different uses. For one thing, Rome's foundation myths were especially suitable for appropriation both within and outside of Renaissance Rome, precisely because they combine stories that emphasize the continuity of location with those that create continuity on the basis of genealogy. Most importantly, however, the ancient discourse offered the Renaissance poets examples of how aetiology could create a privileged link between the ancient Roman past and some desired present.

\section{Bibliography}

Baker, P. (2017). Italian Renaissance Humanism in the Mirror. Cambridge: Cambridge University Press.

Beaune, C. (1985). Naissance de la nation France. Paris: Gallimard. 
Beer, S. de, Enenkel, K. and Rijser, D., edd. (2009). The Neo-Latin Epigram. A Learned and Witty Genre. Leuven: Leuven University Press.

Beer, S. de (2020a). Conrad Celtis' Visions of Rome. Imitation, Contestation and Replacement of the Italian Renaissance in German Humanism. In: C. Horster and M. Pade, edd., Cultural Encounter and Identity in the Neo-Latin World. Rome: Analecta Romana Instituti Danici, pp. 13-32.

Beer, S. de (2020b). Framing Humanist Visions of Rome. Heritage Construction in Latin Literature. In: M. De Pourcq, N. De Haan and D. Rijser, edd., Framing Classical Reception Studies. Leiden/Boston: Brill, 201-226.

Beer, S. de (forthcoming). The Memory of Augustus and Augustan Rome in Humanist Latin Poetry. In: M. Cavalieri, D. Engels, P. Assenmaker and M. Cavagna, edd., Augustus through the Ages. Brussels: Latomus.

Benzi, F. (1990). Sisto IV Renovator urbis. Architettura a Roma 1471-1484. Rome: Officina.

Benzi, F., Crescentini, C. and McGrath, M.B., edd. (200o). Sisto IV. Le arti a Roma nel primo Rinascimento. Rome: Associazione Culturale Shakespeare and Company.

Bianchi, R. (2004). Paolo Spinoso e l'umanesimo romano nel secondo Quattrocento. Rome: Edizioni di Storia e Letteratura.

Blondin, J. (2005). Power Made Visible. Pope Sixtus IV as Urbis Restaurator in Quattrocento Rome. The Catholic Historical Review, 91(1), pp. 1-25.

Borchardt, F. (1971). German Antiquity in Renaissance Myth. Baltimore/London: John Hopkins.

Celtis, C. (1963). Fünf Bücher Epigramme. Edited by K. Hartfelder. Hildesheim: Olms.

Celtis, C. (2001). Die Germania generalis. Studien mit Edition, Übersetzung und Kommentar. Edited by G. Müller. Tübingen: Niemeyer.

Celtis, C. (2003). Panegyris ad duces Bavariae. Edited and translated by J. Gruber. Wiesbaden: Harrassowitz.

Christian, K. (2010). Empire without End. Antiquities Collections in Renaissance Rome, c. 1350-1527. New Haven/London: Yale University Press.

Collins, D. (2012). The Germania illustrata, Humanist History, and the Christianization of Germany. In: K. Van Liere, S. Ditchfield and H. Louthan, edd., Sacred History. Uses of the Christian Past in the Renaissance World. Oxford: Oxford University Press, pp. 101-120.

Dandelet, T. (2014). The Renaissance of Empire in Early Modern Europe. Cambridge: Cambridge University Press.

De Luca, G. (1938). Un umanista fiorentino e la Roma rinnovata da Sisto IV. La Rinascita, 1, pp. 74-9o.

Du Bellay, J. (1966). Les Regrets et autres oeuvres poétiques. Edited by J. Jolliffe, with an introduction and commentary by M. Screech. Geneva: Droz.

Du Bellay, J. (1984). Oeuvres Poétiques, vol. 7: Oeuvres Latines. Poemata. Edited and translated by G. Demerson. Paris: Librairie Nizet. 
Du Bellay, J. (2006). The Regrets, with The Antiquities of Rome, Three Latin Elegies, and The Defense and Enrichment of the French Language. A Bilingual Edition. Edited and translated by R. Helgerson. Philadelphia: University of Pennsylvania Press.

Edwards, C. (1993). The Politics of Immorality in Ancient Rome. Cambridge: Cambridge University Press.

Edwards, C. (1996). Writing Rome. Textual Approaches to the City. Cambridge:Cambridge University Press.

Edwards, C. (2015). The City in Ruins. Text, Image, Imagination. In: P. Erdkamp, ed., The Cambridge Companion to Ancient Rome. Cambridge: Cambridge University Press, pp. 541-557.

Enenkel, K. and Ottenheym, K. (2017). Oudheid als ambitie. De zoektocht naar een passend verleden 1400-1700. Nijmegen: Vantilt.

Fantuzzi, M. and Rüpke, J. (2006). Aetiology. In: H. Cancik and H. Schneider, edd., Brill's New Pauly Online. Available at: http://dx.doi.org/10.1163/1574-9347_bnp_e11119o [Accessed 8 March 2018].

Ford, P. (2013). The Judgment of Palaemon. The Contest between Neo-Latin and Vernacular Poetry in Renaissance France. Leiden/Boston: Brill.

Goez, W. (1958). Translatio imperii. Ein Beitrag zur Geschichte des Geschichtsdenkens und der politischen Theorien im Mittelalter und in der frühen Neuzeit. Tübingen: Mohr.

Graham, B. and Howards, P., edd. (2008). The Ashgate Research Companion to Heritage and Identity. Aldershot: Ashgate.

Hardie, P. (1992). Augustan Poets and the Mutability of Rome. In: C. Powell, ed., Roman Poetry and Propaganda in the Age of Augustus. London: Bristol Classical Press, pp. 59-82.

Hardie, P. (2014). The Last Trojan Hero. A Cultural History of Virgil's Aeneid. London: I.B. Tauris.

Hinds, S. (1992). Arma in Ovid's Fasti. Part 2: Genre, Romulean Rome and Augustan Ideology. Arethusa, 25, pp. 113-153.

Hirschi, C. (2012). The Origins of Nationalism. An Alternative History from Ancient Rome to Early Modern Germany. Cambridge: Cambridge University Press.

Horstmann, H. (2010). Ein staunender Franzose in Rom. Joachim du Bellay's Romae descriptio. Antike und Abendland, 56, pp. 181-195.

IJsewijn, J. (1991). Joachim du Bellay's Patriae desiderium. Humanistica Lovaniensia, 40, pp. 244-261.

Jaumann, H. (1999). Das dreistellige translatio-Schema und einige Schwierigkeiten mit der Renaissance in Deutschland. Konrad Celtis' Ode Ad Apollinem (1486). In: G. Vogt-Spira and B. Rommel, edd., Rezeption und Identität. Die kulturelle Auseinandersetzung Roms mit Griechenland als europäisches Paradigma. Stuttgart: Steiner, pp. 335-349. 
Kennedy, D. (1999). Sense of Place. Rome, History, and Empire Revisited. In: C. Edwards, ed., Roman Presences. Receptions of Rome in European Culture 1789-1945. Cambridge: Cambridge University Press, pp. 19-34.

Krebs, C. (2005). Negotiatio Germaniae. Tacitus' Germania und Enea Silvio Piccolomini, Giannantonio Campano, Conrad Celtis und Heinrich Bebel. Göttingen: Vandenhoeck \& Ruprecht.

Krebs, C. (2011). A Most Dangerous Book. Tacitus's Germania from the Roman Empire to the Third Reich. New York: Norton.

Kunst, C. (2006). Sacrum imperium. In: H. Cancik and H. Schneider, edd., Der Neue Pauly Online. Available at: http://dx.doi.org/10.1163/1574-9347_dnp_e152086oo [Accessed 28 February 2018].

Lowenthal, D. (1985). The Past is a Foreign Country. Cambridge: Cambridge University Press.

Lowenthal, D. (1998). The Heritage Crusade and the Spoils of History. Chicago: Chicago University Press.

Martínek, J. (1982). Zu Text und Deutung des Celtis-Epigramms III 40. Listy filologické, 105(4), pp. 233-235.

McKeown, J. (1984). Fabula proposito nulla tegenda meo. Ovid's Fasti and Augustan Politics. In: T. Woodman and D. West, edd., Poetry and Politics in the Age of Augustus. Cambridge: Cambridge University Press, pp. 169-187.

Miglio, M., Niutta, F., Quaglioni, D. and Ranieri, C., edd. (1986). Un Pontificato ed una città. Sisto IV (1471-1484). Rome: Scuola Vaticana di Paleografia.

Muecke, F. (2007). Poetry on Rome from the Ambience of Pomponio Leto. Topography, History, Encomium. L'Elisse. Studi Storici di Letteratura Italiana, 2, pp. 101-126.

Nora, P. et al. (1984-1992). Les lieux de mémoire. 7 vols. Paris: Gallimard.

O'Malley, D. (1968). Giles of Viterbo on Church and Reform. A Study in Renaissance Thought. Leiden: Brill.

Parisi Presicce, C. (2000). I grandi bronzi di Sisto IV dal Laterano in Campidoglio. In: F. Benzi, C. Crescentini and M.B. McGrath, edd., Sisto IV. Le arti a Roma nel primo Rinascimento. Atti del Convegno internazionale di studi. Rome: Associazione Culturale Shakespeare and Company, pp. 188-200.

Pieper, C. (2008). Elegos redolere Vergiliosque sapere. Cristoforo Landinos Xandra zwischen Liebe und Gesellschaft. Hildesheim: Olms.

Renger, J. and Wiesehöfer, J. (2006). Weltreiche, Weltreichsidee. In: H. Cancik and H. Schneider, edd., Der Neue Pauly Online. Available at: http://dx.doi.org/10.1163/ 1574-9347_dnp_e1221020o [accessed 28 February 2018].

Robert, J. (2003). Konrad Celtis und das Projekt der deutschen Dichtung. Studien zur humanistischen Konstitution von Poetik, Philosophie, Nation und Ich. Tübingen: Niemeyer. 
Ronsard, P. de (1993). Oeuvres complètes. Edited byJ. Céard, D. Ménager and M. Simonin. Paris: Gallimard.

Ronsard, P. de. (2010). The Franciad. Translated by P. Usher. New York: AMS Press.

Rotondò, A. (1972). Aurelio Lippo Brandolini. In: A. Ghisalberti, ed., Dizionario biografico degli Italiani, vol. 14. Available at: http://www.treccani.it/enciclopedia/ aurelio-lippo-brandolini_(Dizionario_Biografico) [Accessed 30 November 2018].

Spitz, L. (1957). Conrad Celtis, the German Arch-Humanist. Cambridge, Mass.: Harvard University Press.

Stadtwald, K. (1996). Roman Popes and German Patriots. Antipapalism in the Politics of the German Humanist Movement from Gregor Heimburg to Martin Luther. Geneva: Droz.

Stinger, C. (1985). Rome in the Renaissance. Bloomington: Indiana University Press.

Thompson, L. (1990). The Book of Revelation. Apocalypse and Empire. New York/Oxford: Oxford University Press.

Tunbridge, J. and Ashworth, G., edd. (1996). Dissonant Heritage. The Management of the Past as a Resource in Conflict. London: Wiley. 